\title{
Biochemical Characterization of Cassava Processing Waste Water and its Effect on the Growth of Maize Seedlings
}

\author{
${ }^{*}$ S. M. Sam, ${ }^{2}$ G. J. Esenowo and 3. R. Udosen \\ ${ }^{1 *}$ Department of Biological Sciences, Akwalbom State University, IkotAkpaden \\ 2Department of Botany and Ecological Studies, University of Uyo \\ ${ }^{3}$ Department of Biology, Akwa Ibom State College of Education, Afaha Nsit \\ [Corresponding Author: E-mail: sundaysam@aksu.edu.ng, eosamviek@yahoo.com]
}

\section{ABSTRACT}

The effect of cassava processing wastewater from four hybrid varieties of cassava (TMS 92/0057, NR 8082, TMS 92/0326 and TMS 30572), on the germination and early seedling growth of maize was studied in the laboratory. The physicochemical properties of the effluents and elements were analyzed using standard methods. The wastewater from these cassava varieties were highly acidic 4.0, 4.0, 4.10 and 4.20 in contrast to WHO allowable limit of 6.5-8.5 had a low BOD ranging from 1.6 - 2.45, while their HCN ranged from $12.96-16.86 \mathrm{mg} /$ which was observed to be very high as against FAO/WHO admissible maximum limit of less than $10 \mathrm{mg} / \mathrm{kg}$. The germination percentage, growth parameters and biomass were significantly $(P=0.05)$ reduced with increase in the acidic level of the effluents. Higher concentrations of the wastewater were inhibitory to the germination and early seedling growth of maize. The waste water from the four hybrid varieties of cassava increased the level of trace metal elements in Zea mays. Hybrid TMS 92/0326 was less toxic and is recommended to farmers. This study suggests that higher concentrations of cassava processing effluent could be detrimental to the germination and early seedling growth of Zea mays.

Keywords: Biochemical, Characterization, Cassava. Wastewater, Maize

\section{INTRODUCTION}

Maize is a crop belonging to the family of grasses, Poaceae, having the botanical name Zea mays (L.), and cultivated globally being one of the most important cereal crops worldwide. It is a tall, determinate annual $\mathrm{C}_{4}$ plant varying in height from 1 to 4 meters producing large, narrow, opposing leaves (about a tenth as wide as they are long), borne alternately along the length of a solid stem. Maize is wind pollinated and both self and cross pollination is usually possible.Shed pollen usually remains viable for 10 to 30 minutes, but can remain viable for longer durations under favorable conditions (Coe et al., 1988).

Maize crop is primarily a warm weather crop and it is grown in wide range of climatic conditions (ICAR, 2006). Maize can successfully be grown in areas receiving an annual rainfall of $60 \mathrm{~cm}$, which should be well distributed throughout its growing stage. It needs more than $50 \%$ of its total water requirements in about 30 to 35 days after tasseling and inadequate soil moisture at grain filling stage results in a poor yield and shriveled grains.

Waste water from cassava processing released directly into the environment before proper treatment serve as a source of pollution. In many areas where traditional processing is practiced, it's normally discharged beyond 'factory' walls into road side ditches or fields and allowed to flow freely, settling into depressions. Eventually, this will percolate into the subsoil or flow into streams. High concentrations of cyanide have been shown to contaminate ground water supply during rainfall causing a foul environment, and may kill plants and aquatic life in the nearby water bodies (Cereoda and Takahashi, 1996). Ehiagbonare et al. (2009) investigated the effect of cassava effluent on the environment and found out that the effluent had negative effect on plants, air, domestic animals, soil and water from the 
results of the various parameters investigated. In spite of all these findings, the treatment and disposal of cassava wastewater from industrial sources is still a major problem in Nigeria.

Compounds that are generally toxic to living organisms will also prevent the germination as well as inhibit growth of plants at toxic concentrations. The growth of various crops has been reported to be influenced by different types of effluents. Orhue et al. (2008) observed that soil treated with brewery effluent showed increased $\mathrm{K}, \mathrm{CO}_{2}, \mathrm{C} / \mathrm{N}$ ratio and $\mathrm{pH}$ and enhanced the growth of maize. Napu grass productions have been shown to increase significantly with rubber effluent application (Tan et al, 1979). Sugar factory effluents have been shown to increase soil organic matter by $1.5 \%$. Palm oil processing effluent has been reported to retard the germination of Zea mays at high concentrations (Essien and Odoemena, 2005). There are reports on the effect of tannery effluent on seed germination (Karunya let al., 1994), contaminating effect of spent engine oil on plant growth (Anoliefo and Edegai, 2001) and heavy metal accumulation in vegetables grown in mine wastes (Cobb et al., 2005) etc. However, there's not much literature on the effects of cassava effluent on plant growth. At present, the effect of cassava processing effluent from these hybrid varieties newly introduced into Akwa lbom State, on the germination and early seedling growth is not clearly documented as such this studies aim to determine the physico-chemical properties of cassava processing waste water and its effect on germination and early seedling growth of maize.

\section{MATERIALS AND METHODS}

The different hybrid varieties of cassava namely TMS 92/0057, TMS 92/0326, NR 8082 and TMS 30572 were collected from Akwa lbom Agricultural Development Program (AKADEP), Uyo, while the maize seeds were obtained from a local cultivar. The waste water was generated from the traditional production method for garri production, following the procedure of Okafor (1997) and was obtained from a local cassava processing factory located at Abak, Akwa Ibom State. Ten (10) litres of wastewater was collected from each variety with a sterile rubber container and stored in a refrigerator at $20^{\circ} \mathrm{C}$ until needed. The physical and chemical parameters of the cassava waste effluent were determined using standard procedures for examination of water and waste water (APHA, 1989). The physical parameters analyzed were temperature at the time of collection, $\mathrm{pH}$, conductivity, suspended solids (SS), while the chemical parameters were Biochemical Oxygen Demand (BOD) (mg/L), total cyanide content $(\mathrm{mg} / \mathrm{L})$, Chemical Oxygen Demand (COD) and the elements analyzed for were: phosphate (Po42-), sodium $\left(\mathrm{Na}^{+}\right)$, calcium $\left(\mathrm{Ca}^{2+}\right)$ and potassium $\left(\mathrm{K}^{+}\right)$. These analyses were carried out using the Atomic Absorption Spectrometer (AAS) method as described in APHA (1989). The above parameters were analyzed at the Chemistry laboratory, Akwa Ibom State University.

Determination of Sodium, Potassium, Calcium One thousand parts per million stock solution of sodium $\left(\mathrm{Na}^{+}\right)$, potassium $\left(\mathrm{K}^{+}\right)$, calcium $\left(\mathrm{Ca}^{2+}\right)$ were prepared. The standard ( $\mathrm{Na}, \mathrm{K}, \mathrm{Ca})$ and sample solutions as well as the blank solutions were aspirated using a flame photometer (GallenKamp BKL - 210) with the filter of $\mathrm{Na}^{+}, \mathrm{K}^{+}$, $\mathrm{Ca}^{2+}$ in place and the readings ofelements in the sample solutions recorded asdescribed by Salami and Egwin (1997).

The effluent was prepared in various concentrations of $0 \%, 25 \%, 50 \%, 75 \%$ and $100 \%$ respectively using a simple serial dilution with sterile deionized water. Sterile distilled water was used as $0 \%$. After sterilization with bleach, seeds were then spread on sterile Whatman's No. 2 filter paper moistened with $10 \mathrm{ml}$ of the various concentrations of the cassava liquor. Three replicates were used following the methods of (Esenowo, 1991). The effluents were replenished as need arose and the criterion for seed germination was taken as protrusion of the radical up to $2 \mathrm{~mm}$ at the time of observation 
(Singh and Mishra, 1987) and the experiments were made to stay for 14 days.

The growth parameters (height of seedlings, root length, leaf length and width) were measured in centimeters after 14 days. The dry weights of the seedlings were determined by oven drying at $80^{\circ} \mathrm{C}$ for 48 hours. The difference between fresh weight and the dry weight of the seedlings were regarded as moisture contents.

Data on germination percentage and growth parameters of the seedlings were subjected to Analysis of Variance (ANOVA), following the methods of Little and Hills (1972). The levels of five trace metal elements viz. $\mathrm{Pb}$ (Lead), $\mathrm{Ni}$ (Nickel), V (Vanadium), $\mathrm{Cr}$ (Chromium) and $\mathrm{Cd}$ (Cadmium) were analyzed in cassava varieties using UNICAM 939 spectrometer. The trace elements and distilled water were analyzed with UNICAM 939 Atomic Absorption Spectrometer.

\section{RESULTS}

Table 1 shows the physical and chemical properties of the different samples of the cassava processing effluent from the four varieties of cassava that were used. The $\mathrm{pH}$ of the four samples were 4.20, 4.0, 4.10, and 4.20 respectively and was acidic which is in contrast to the admissible limits of $6.5-8.5$ for $\mathrm{pH}$ value in effluent water as stated by WHO (2004). The conductivity ranged from 11.28 to $22.28 \mathrm{dS} / \mathrm{m}$ which were low compared to WHO (2004) standard of 750.5 with TMS $92 / 0057$ being the highest, while suspended solids ranged from 44 to $241 \mathrm{mg} / \mathrm{L}$. The suspended solid of TMS 90/0326 and TMS 30572 were higher than TMS 92/0057 and NR 8082. The phosphate ranged from $8.81-11.65 \mathrm{mg} / \mathrm{L}$, calcium ranged from 1200 to $1800 \mathrm{mg} / \mathrm{L}$ with NR 8082 being the highest, sodium ranged from $24-30 \mathrm{mg} / \mathrm{L}$, potassium ranged from $6000-6600 \mathrm{mg} / \mathrm{L}$ with TMS 92/0057 being the highest, HCN was $15.12,12.96,16.86$ and $16.11 \mathrm{mg} / \mathrm{L}$ which was observed to be very high as against FAO/WHO (1991a) admissible maximum limit of less than $10 \mathrm{mg} / \mathrm{kg}$. However, the BOD was quite low.

Figures 1 to 10 show the growth parameters of maize seedlings using the wastewater samples from the four varieties of cassava. At the highest concentration of the effluents $(100 \%)$, germination and overall growth of the plant were inhibited except with variety TMS 93/0326, which had poor germination and growth.In all the varieties tested, the germination percentage and growth parameters were significantly $(p<0.05)$ reduced with increased effluent concentration. There were also significant $(p<0.05)$ reduction in fresh weight, dry weight and moisture content with increased effluent concentration (Figures 8, 9 and 10) respectively.

The lead content of all the varieties was very high as compared to the control. It ranged from 171.15 -229.0 (mg/L) while the control was $10.80 \mathrm{mg} / \mathrm{L}$. Other trace metals significantly $(p<0.05)$ increased above the control (Table 2).

\section{DISCUSSION}

The physical and chemical of properties of cassava processing wastewater showed that the $\mathrm{pH}$ is acidic which is in contrast to the admissible limits of 6.5-8.5 for $\mathrm{pH}$ value in effluent water as stated by WHO (2004). The high values of $\mathrm{pH}$ may be attributable to the presence of prussic acid (Gibbson and Pain, 1985). Therefore, the effluent if untreated before discharge into the environment is a potential source of water pollution within the vicinity. Also the level of cyanide content was observed to be very high as against FAO/WHO (1991a) admissible maximum limit of less than $10 \mathrm{mg} / \mathrm{kg}$. However, the high level of cyanide level can cause ill-health and ultimately death in human and aquatic biota (Ademoroti, 1996b). The electrical conductivity of the four effluent samples was low indicating low presence of conducting ions.

\section{Table 1: Physicochemical Analysis of the Cassava Processing Effluent of varieties A-D}


Nigerian Journal of Basic and Applied Science (December, 2017), 25(2): 12-20

\begin{tabular}{lccccc}
\hline \multicolumn{1}{c}{ Parameters } & $\begin{array}{c}\text { Sample } \\
\text { A }\end{array}$ & $\begin{array}{c}\text { Sample } \\
\text { B }\end{array}$ & $\begin{array}{c}\text { Sample } \\
\text { C }\end{array}$ & $\begin{array}{c}\text { Sample } \\
\text { D }\end{array}$ & $\begin{array}{c}\text { WHO Standard } \\
(\mathbf{2 0 0 4})\end{array}$ \\
\hline pH & 4.20 & 4.00 & 4.10 & 4.00 & $6.5-8.5$ \\
Conductivity $(\mathrm{dS} / \mathrm{m})$ & 22.28 & 11.28 & 16.78 & 15.32 & 750.5 \\
Suspended Solid $(\mathrm{mg} / \mathrm{L})$ & 44.00 & 46.00 & 230.00 & 241.0 & 25 \\
Phosphate $(\mathrm{mg} / \mathrm{L})$ & 8.81 & 10.00 & 10.00 & 11.65 & - \\
Sodium $(\mathrm{mg} / \mathrm{L})$ & 24.00 & 25.00 & 26.00 & 30.00 & - \\
Calcium $(\mathrm{mg} / \mathrm{L})$ & 1200.0 & 1800.0 & 1560.0 & 1440.0 & - \\
Potassium $(\mathrm{mg} / \mathrm{L})$ & 6600.0 & 6400.0 & 6000.0 & 6100.0 & - \\
HCN $(\mathrm{mg} / \mathrm{L})$ & 15.12 & 12.96 & 16.86 & 16.11 & 10 \\
BOD & 1.633 & 2.45 & 2.36 & 2.08 & 10 \\
\hline
\end{tabular}

Table 2: Trace Metal Levels from the Effluents of varieties A-D

\begin{tabular}{llllll}
\hline Samples & $\mathrm{Pb}(\mathrm{Mg} / \mathrm{L})$ & $\mathrm{Ni}(\mathrm{Mg} / \mathrm{L})$ & $\mathrm{V}(\mathrm{Mg} / \mathrm{L})$ & $\mathrm{Cr}(\mathrm{Mg} / \mathrm{L})$ & $\mathrm{Cd}(\mathrm{Mg} / \mathrm{L})$ \\
\hline Control & 10.80 & 2.44 & 0.60 & 0.08 & 0.10 \\
$\mathrm{~A}$ & 171.15 & 8.430 & 1.114 & 0.180 & 0.451 \\
$\mathrm{~B}$ & 194.6 & 3.716 & 1.632 & 0.131 & 0.226 \\
$\mathrm{C}$ & 229.0 & 8.441 & 1.422 & 0.103 & 0.238 \\
$\mathrm{D}$ & 227.6 & 8.436 & 1.220 & 0.101 & 0.218 \\
\hline
\end{tabular}

Key: A=TMS 92/0057; B = NR-8082; C =TMS 92/0326; D = TMS 30572

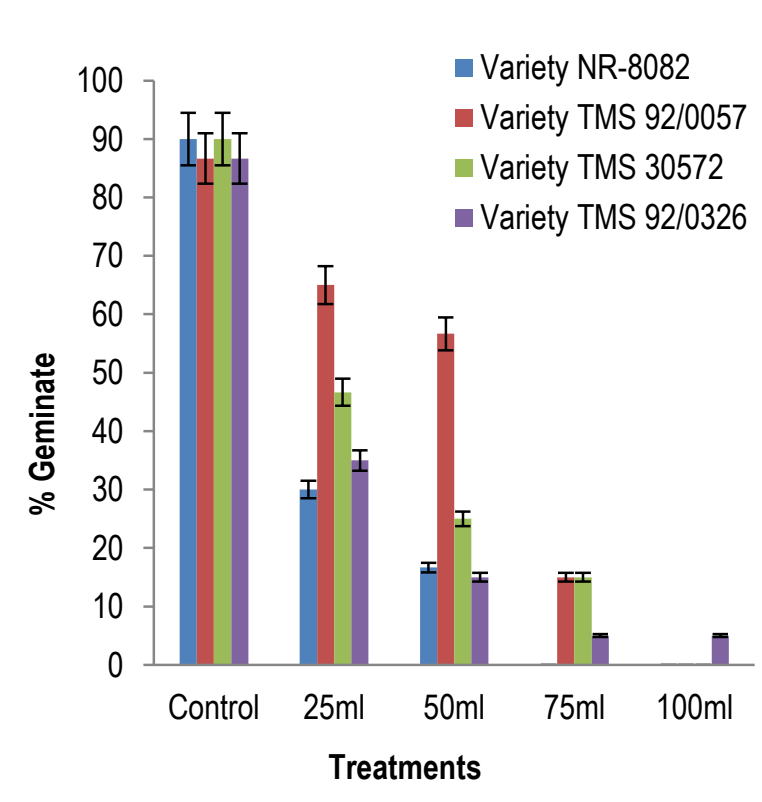

Figure 1: The effect of cassava processing waste water on \% Germination of Zea mays varieties

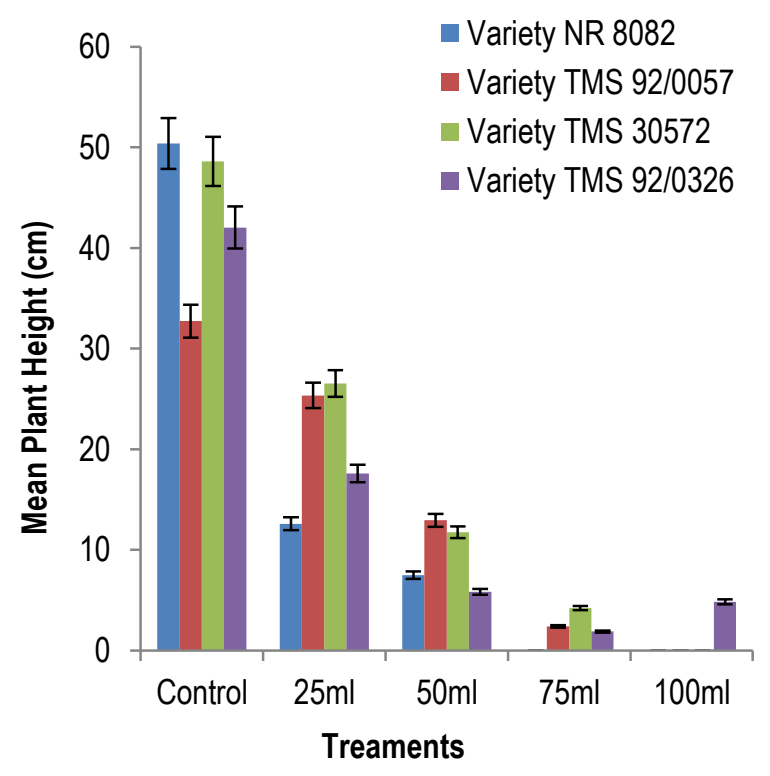

Figure 2: The effect of cassava processing wastewater on Plant height of Zea mays varieties 


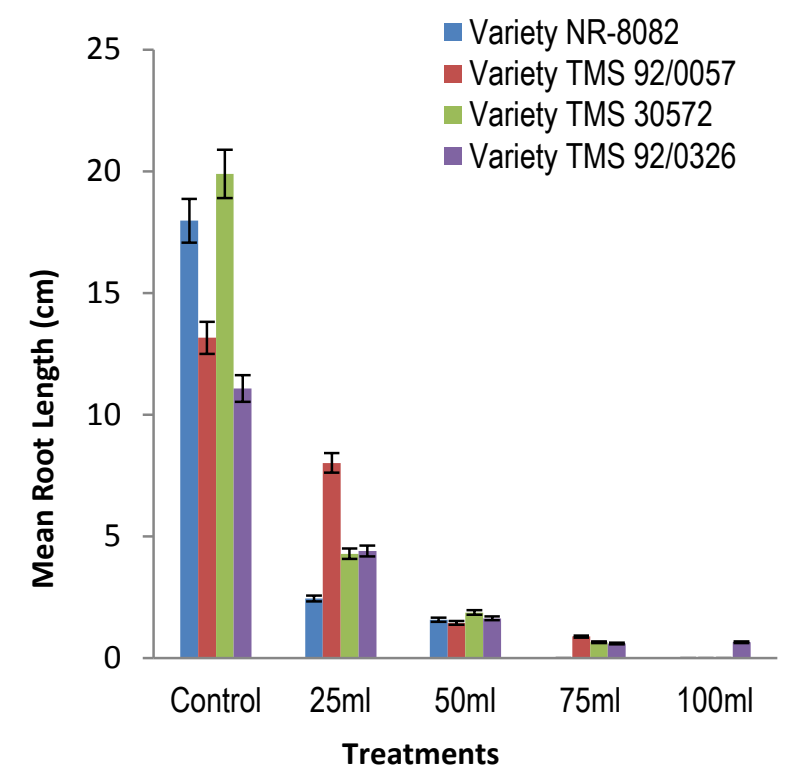

Figure 3: The effect of cassava processing waste water on root length of Zea mays varieties

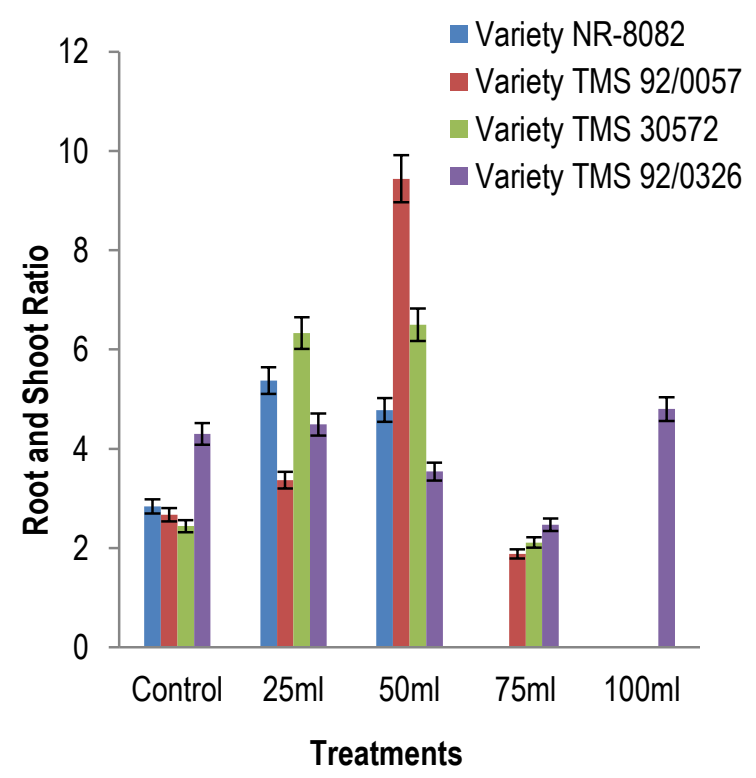

Figure 4: The effect of cassava processing waste water on Root and Shoot Ratio of Zea mays Varieties

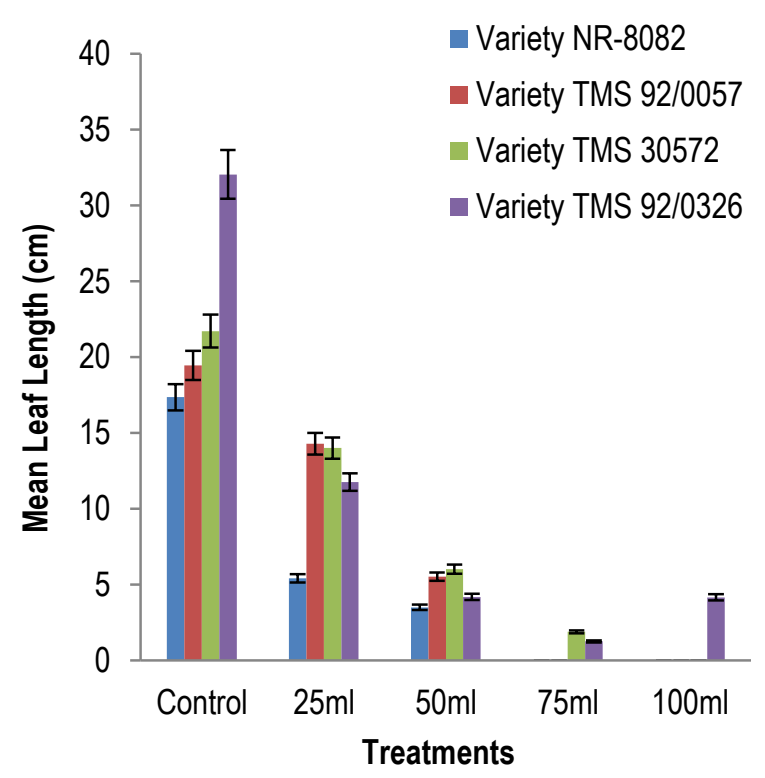

Figure 5: The effect of cassava Processing Waste Water on Leaf Length of Zea mays varieties

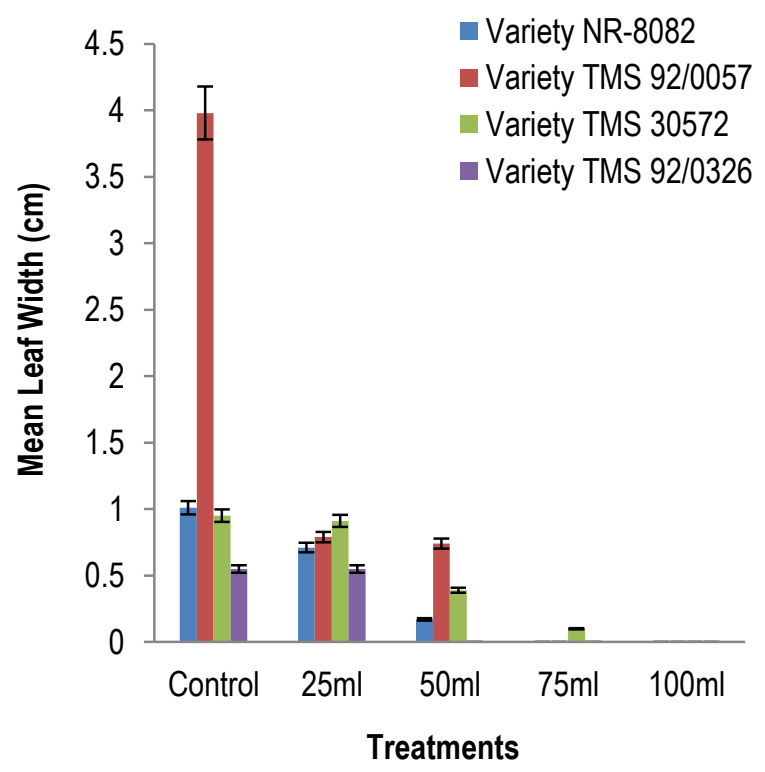

Figure 6: The effect cassava processing Waste Water on Leaf Width of Zea mays varieties 


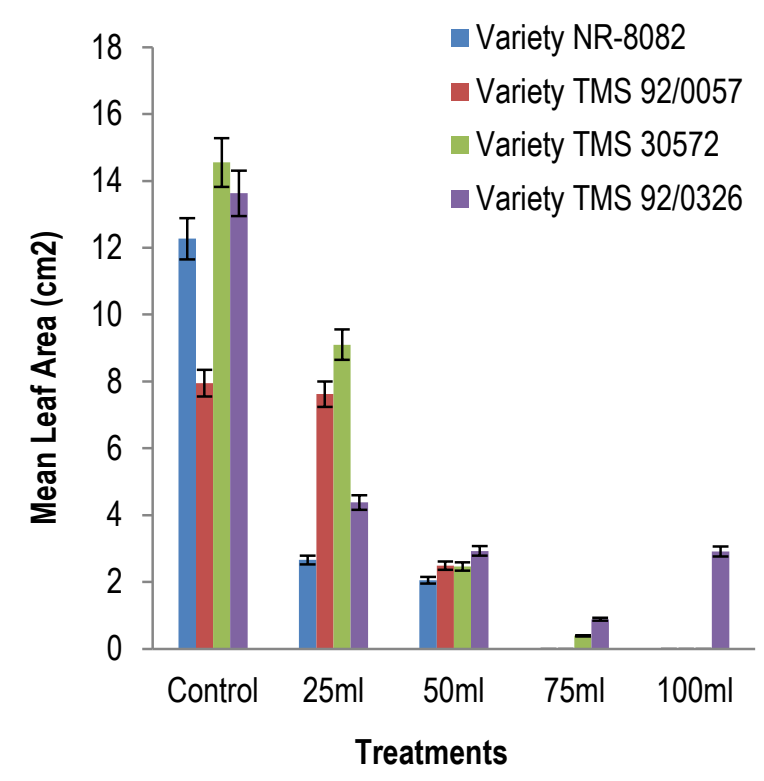

Figure 7: The effect of cassava processing waste water on Leaf Area of Zea mays varieties

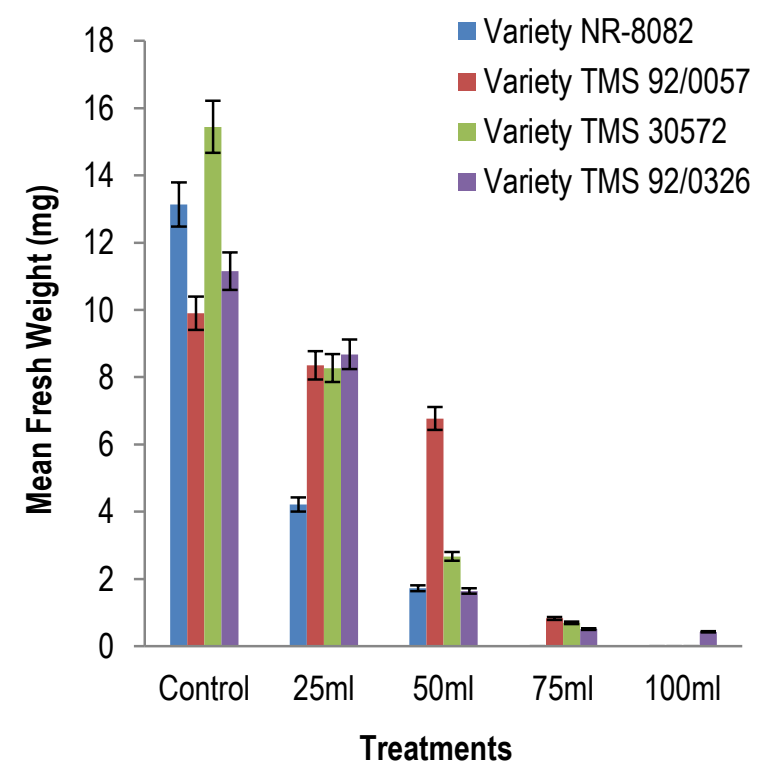

Figure 8: The effect of cassava processing waste water on Mean Fresh Weight of Zea mays varieties

Generally, all the effluents have slightly irritating odour and this goes to explain the odious smell that is normally associated with garri processing industry and its surrounding. These are indexes of highly polluted cassava processing waste water that may be very detrimental to plant growth. The presence of these properties may affect seed germination and growth.

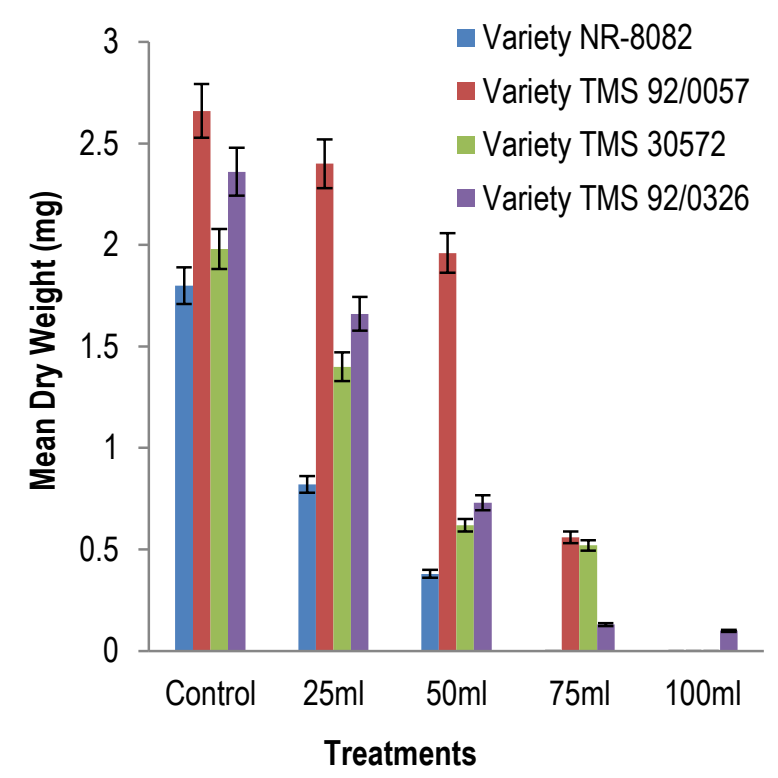

Figure 9: The effect of cassava processing Waste Water on the Mean Dry Weight of Zea mays varieties

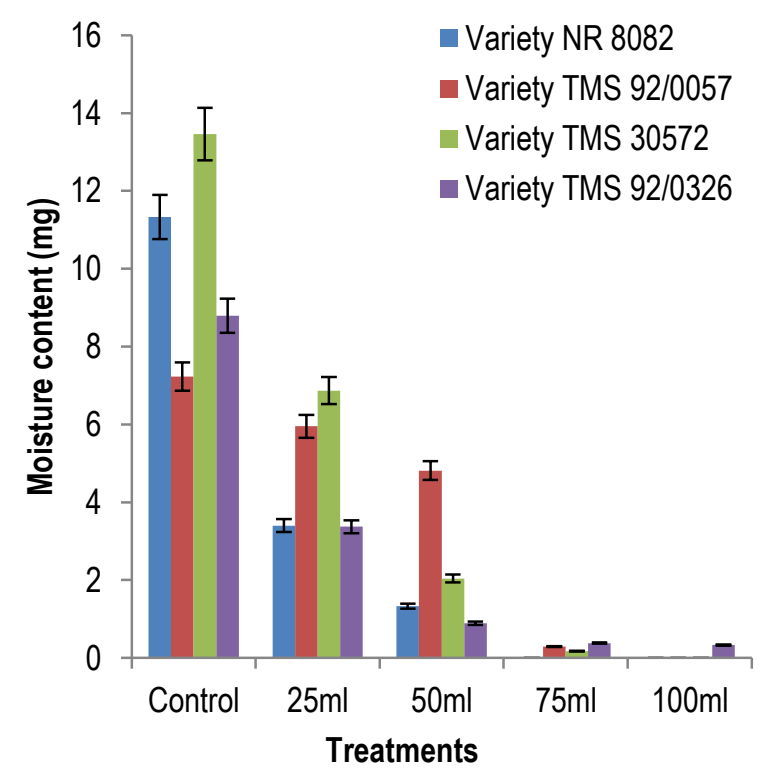

Figure 10: The Effect of Cassava Processing Waste Water on Moisture Content of Zea mays varieties 
These pollutant indicators as shown on Table 1 can therefore be reduced in their units when the effluents are treated with suitable active carbons as documented by Okafor and Egwin (2004) in which it was reported thattreatment of cassava effluent with locally developed adsorbents reduced $\mathrm{BOD}$ and $\mathrm{COD}$ by up to 50 and $75 \%$ respectively. High values for calcium and potassium were also observed. Potassium is very important in plant growth; its deficiency affects the growth of the plant severely because it stimulates early plant growth, increases protein production, improves the efficiency of water use and improves resistance to diseases and insects. There were significant $(p<0.05)$ reductions in the percentage germination and growth parameters of maize seedlings with increased levels of wastewater tested. The low rate in germination was probably due to toxicity resulting from effluent contamination around the seeds. This agrees with the findings of Dutta and Biossyna (1997) that worked on the effect of paper mill effluent on germination of rice seed and growth behavior of its seedlings and discovered that effluents particularly at higher concentration inhibit germination. Rajni and Chauchan (1996) discovered in their investigation that the effect of tannery effluent on seed values of Hordeum vulgaris $\mathrm{L}$. showed that the effluents caused a significant reduction in germination percentage. Ogunwenmo et al. (2010) also found out that paints effluents generally inhibited the germination of Leafy vegetables-Amaranthus hybridus and $C$. argentea. The reduction in growth parameters may also be due to heavy metal poisoning, as a result of high concentration of heavy metals like lead. The reduction in BOD observed showed that the oxygen available in the waste water is not completely consumed by the bacteria and the dissolved oxygen (DO) levels increased, indicating a small amount of organic pollution. When the BOD increases, there is an increase in the organic pollution and consequent decrease in DO. When all DO in the waste water is used up, anaerobic conditions set in resulting in offensive odours. Most fish and aquatic organisms hardly survive in water polluted with waste water (Henry and Howeler, 1996). The fresh and dry weights significantly $(p<0.05)$ decreased with increase in cassava processing waste water. This reduction may be due to a reduction in the proportionate amount of nutrients and biomass at the elongation phase of seedlings (Mayer et al., 1973), or due to low water potential of the cassava processing effluents which weakened nutrient absorption in combination with the acidic nature of the cassava processing waste water. This result is in line with the study of Pandey et al (1994), who showed that there was significant reduction in the fresh weight of seedlings. The cassava processing wastewater had high levels of $\mathrm{Pb}, \mathrm{Ni}, \mathrm{V}, \mathrm{Cr}$ and $\mathrm{Cd}$ as compared to the control. Lead was found to be a major heavy metal constituent in cassava effluents. This result is in line with the study of Heidari et al. (2005) reported that Zea mays is a $\mathrm{Pb}$ tolerant plant and that $\mathrm{Pb}$ metal ions accumulate mostly in their roots and shoots (Malkowski et al., 1996). Heavy metals disrupt the metabolic processes of living organism by inducing anatomical changes in primary leaves (Chaudhry and Qurat-ul-Ain, 2003).It could have been that the high rate of pollution enhanced the production of trace elements. Similar observations were made by Lowei (1968), who showed that increased levels of trace elements were indicative of extensive pollution. Therefore,these results should be a source of major concern not only to farmers with garri processing industries within theirsurroundings but to all others whodischarge such effluents indiscriminately withoutadequate prior treatment.

\section{CONCLUSION}

The cassava waste water characteristics showed some values of the physicochemical parameters exceeded the World Health Organization Standard for industrial wastewaters therefore not safe for direct discharge in farmlands. The electrical conductivity of the four effluent samples was low indicating low presence of conducting ions while the $\mathrm{pH}$ values showed the effluent was acidic. This study also revealed the bio- 


\section{Nigerian Journal of Basic and Applied Science (December, 2017), 25(2): 12-20}

concentration of heavy metals in plants and its attendant toxicity and continued discharge industrial cassava waste water effluent could lead to further deterioration of the ecosystem.

\section{REFERENCES}

Ademoroti, C.M.A. (1996b). Environmental Chemistry andToxicology, Foludex Press Ltd., Ibadan, Nigeria.

Anoliefo, G. O. and Edegbai, B. O. (2001). Effect of spent engine oil as a soil contaminant on the growth of two egg Nant species, Solanum melongena (L.) and S. incanum (L.). Journal of Agriculture, Forestry and Fisheries, 1:21-25

APHA (1989). Standard methods for the examination of water and wastewater. American Public Health Association, 17th edition pp. $110-200$.

Chaudhry, N.Y. and Qurat-ul-Ain, (2003). Effect of growth hormones i.e., IAA, Kinetin and heavy metal i.e., lead nitrate on the internal morphology of leaf of Phaseolus vulgaris L. Pakistan Journal of Biological Sciences, 6: 157-163.

Cereda, M. P. and Takahashi, M. (1966). Cassava wastes. Their characterization; uses and treatment in Brazil pp. 16 -25.

Cobb, G. P., Sands, K., Waters, M., Wixson, B. G. and Dorward-King, E. (2005). Accumulation of heavy metals by vegetables grown in mine wastes. Environmental Toxicology and Chemistry, 19:600-609

Coe, E. H. Jr., Nueffer, M. G. and D. A. Hoisington (1988). The genetics of maize.In G.F Sprague and J.W. Dudley, Eds. Corn and corn improvement. Agronomy Monographs American Society of Agronomy: Madison, Wisconsin, 18; 220-236.

Dutta, S.K. and Boissya, C. L. (1997). Effect of paper mill effluent on germination of rice (Oryza sativa L.) and growth behaviour of its seedlings. Journal of Industrial Pollution Control, 13:41-47.
Ehiagbonare, J. E., Enabulele, S. A., Babatunde, B. B. and Adjarhore, R. (2009). Effect of Cassava Effluent on Okada denizens. Scientific Research and Essay, 4(4): 310-313.

Esenowo, G. J. (1991). Developmental Biology and Plant Physiology. Abaam Publishing co. Kaduna, Nigeria, pp. 221-250

Essien E. P. and Odoemena, C. S. (2005). The effect of palm oil processing effluent on germination and early seedling growth of Zea mays L. Journal of Sustainable Tropical Agricultural Reasearch, 16:72 76.

FAO/WHO (1991a). Joint FAO/WHO food standard programme. Codex Alimentalius Commission. XII Suppl. 4Ed. Rome: FAO pp1-42

Gibbon, D and Pain, A. (1985). Crops of the Drier Region ofthe Tropics, England Longman Group, U.K.

Heidari, R., M. Khayami and T. Farboodnia, (2005). Effect of $\mathrm{pH}$ and EDTA on Pb ccumulation in Zea mays seedlings. Journal of Agronomy, 4: 49-54.

Henry, G., Howeler, R. (1996). Cassava in China in an era of change. A CBN case study with farmers and processors. Working Document No. 155. CIAT, Cali, Columbia p. 18.

ICAR, (2006). ICAR Guidelines for Intellectual Property Management and Technology Transfer/Commercialization. Indian Council of Agricultural Research, New Delhi.

Little T. M. and Hills, G. D. (1972). Statistical Methods in Agricultural Research, Cooperative and Extension work in Agricultural and Home Economic, California, U.S.A. pp. $40-47$.

Lowei, B. (1986). Effect of Bowl Sludge on growth of two pasture legumes, Brachia mutica and Axonopus compressus. Malaysia Journal of Agriculture 25:19 31.

Malkowski, E., Stolarek, J. and Karcz, W. (1996). Toxic effect of $\mathrm{Pb}^{2+}$ ions on extension 
growth of cereal plants. Polish Journal of Environmental Studies, 5: 41-45.

Mayer, B. S., Anderson, D. B., Bohning, R. H. and Friatiana D. G. (1973). Introduction to Plant Physiology $2^{\text {nd }}$ edition, D. Van Nostrand Company - New York. pp. 431 $-463$.

Ogunwenmo, K. O., Oyelana, O. A. Ibidunmoye, 0 . Anyaso, G. and Ogunnowo, A. A. (2010). Effects of brewery, textile and paint effluent on seed germination of leafy vegetables-Amaranthushybridus and Celosia argentea (Amaranthaceae). Journal of Biological Sciences.,10:151156.

Okafor, G. E. (1997). Effect of Effluent Quality and Application Method of Agricultural Productivity and Environment Control.Water Science and Technology 26: $1593-1601$.

Okafor, J.O. and Egwim E. (2004). Effect of Chemically andPhysically treated Adsorbents on wastewater fromGarri Processing Industry, 27th Annual International Conference of Chemical Society ofNigeria, Benin City, Nigeria. 21stto 22nd August.

Orhue, E. H., Ulamen, C. and Emuejevoke, V. D. (2005). Growth of maize and changes in some chemical properties of an utisol amended with brewery effluent. African Journal of biotechnology 12:973-978.
Pandey, D. K., Soni, P. and Dhiman R. C. (1994). Utilization Potential of Distillery effluent VOSANA 38:12 - 13.

Rajni, A. and S.V.S. Chauchan(1996).Effect of tannery effluent on seed germination and total biomass in some varieties of Hordeum vulgare L. Acta Ecol., 18: 112115.

Salami, S.J. and Egwin I.N. (1997). Impact of TanneryEffluents on the Quality of Receiving Stream,African Journal of Natural Sciences, 2(1) pp 17-20.

Singh, K. K. and Mishra, R. (1987). Effect of Fertilizer Factory on Soil and Crop Productivity.Journal of Water, Air and Soil Pollution 33:309 - 320.

Tan, H., Pillai, K. P. and Bary, D. J. (1979). Possible Utilization of Rubber Factory Effluent on Cropland. Proceeding of Rubber Research Institute of Malaysia, Kuaba Lampur, pp.154.

World Health Organization (WHO), (2004). Maximum Allowable Concentration of Selected Water Quality Variables. 